\title{
STUDIES ABOUT MATHEMATICS IN ELEMENTARY SCHOOL VIEWED FROM PREVIOUS AND CURRENT CURRICULUM
}

\author{
Andri Anugrahana \\ Sanata Dharma University \\ Email: andrianugrahana@gmail.com
}

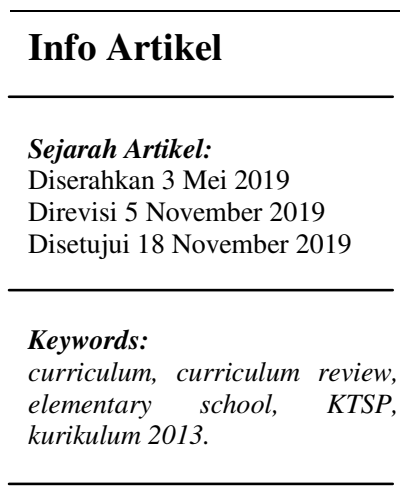

\begin{abstract}
The aims of this study is to describe the position of mathematics learning in the curriculum of Kurikulum 2013 (K13) when compared to the previous curriculum. namely Kurikulum Tingkat Satuan Pendidikan (KTSP).

This research is literature study, with a qualitative approach. Data was collected by analyzing the K13 and KTSP. The data source is the curriculum that applies in Indonesia, they are k13 and KTSP for elementary schools. Data analysis was carried out by: (1) analyzing the scope of mathematical material by looking at SK and KD class 1 to grade 6 in the KTSP curriculum and curriculum 2013; (2) looking for differences from each material scope in each class, class 1 to grade 6 in the curriculum K7SP and also the K13; and (3) search for material coverage, namely the concept of numbers, geometry, measurement and statistics in the old and new curriculum in elementary school.

The results of the study are (I) The analysis of the scope of material in grades 1 through 6 on the 2013 KTSP and curriculum curriculum; The differences in material coverage at each level is class 1 to grade 6, and (3) Material coverage, namely the concepts ,r1 numbers, geometry, measurement and statistics for the K13 and KTSP for elementary school.
\end{abstract}

\begin{abstract}
Abstrak
Penelitian ini bertujuan untuk mendeskripsikan posisi pembelajaran matematika dalam Kurikulum 2013 jika dibandingkan dengan kurikulum yang sebelumnya yaitu Kurikulum Tingkat Satuan Pendidikan (KTSP).

Penelitian ini merupakan studi literasi dengan pendekatan kualitatif. Data dikumpulkan dengan melakukan analisis kurikulum 2013 dan KTSP. Sumber data adalah kurikulum yang berlaku di Indonesia yaitu kurikulum lama yaitu KTSP dan kurikulum baru yaitu kurikulum 2013 di sekolah Dasar. Analisis data dilakukan dengan 1) menganalisis cakupan materi matematika dengan melihat SK dan KD kelas 1 sampai kelas 6 yang ada di kurikulum KTSP dan kurikulum 2013. 2) Mencari perbedaan dari setiap cakupan materi di setiap kelasnya yaitu kelas 1 sampai kelas 6 yang ada dalam kurikulum KTSP dan juga kurikulum 2013. 3) mencari cakupan materi yaitu konsep bilangan, geometri, pengukuran dan statistika yang ada di kurikulum lama dan baru di sekolah dasar.

Hasil penelitian sebagai berikut. Pertama, analisis cakupan materi yang ada di kelas 1 sampai kelas 6 pada kurikulum KTSP dan kurikulum 2013. Kedua, perbedaaan cakupan materi di setiap jenjangnya yaitu kelas 1 sampai kelas 6 , dan yang ketiga cakupan materi yaitu konsep bilangan, geometri, pengukuran dan statistika yang ada di kurikulum lama dan baru di sekolah dasar.
\end{abstract}

(C) 2019 Universitas Muria Kudus 
Andri Anugrahana

STUDIES ABOUT MATHEMATICS IN ELEMENTARY SCHOOL VIEWED FROM ... REFLEKSI EDUKATIKA: Jurnal Ilmiah Kependidikan 10 (1) Desember 2019. Hlm. 18-28

\section{INTRODUCTION}

The government always strive to improve the quality of education by constantly changing the curriculum. Changes to the curriculum in a certain period of time are part of the policies made by the government. Changes to the curriculum were made to improve the quality of education and also to keep up with time. Karli (2014) The curriculum will continue to develop and change in accordance with time. It is a program that is made and implemented to achieve an educational goal. It can also be interpreted as a program in the form of program documents and program implementation. As a curriculum document (curriculum plan), it is written in forms of details of the course, syllabus, lesson plan, and achievement evaluation system. Meanwhile, the curriculum as a program implementation is a form of actual teaching and learning (actual curriculum). Usually, the focus of curriculum change is mainly about paper works, but the implementation of learning, the creation of a learning atmosphere, ways of learning evaluation / assessment, often did not change much. Therefore, it can be said that curriculum changes are only at the concept level or just document changes. This can be seen in the old education system where the curriculum was used as an input aspect only. (Academic, 2008).

In a curriculum development in 2006, the curriculum is used as a reference or guideline in conducting learning activities. These learning activities aim to achieve national education goals in accordance with local / regional context. In its development. Kurikulum Tingkat Satuan Pendidikan/KTSP (Curriculum for Each Education Level) aims to achieve national education. The purpose of KTSP is to give students chances to: learn about their faith and obey God, learn to understand and appreciate, learn to carry out and do things effectively, learn to live together and be useful to others, and learn to build and find identity through an active, creative, effective and fun learning process. (KTSP, 2006)

Before July 2013, the educational system in Indonesia used curriculum prepared at the school level (Kurikulum Tingkat Satuan Pendidikan, KTSP). KTSP was implemented since July 2006. KTSP was developed by each school, in accordance with the conditions of the school, regional characteristics, social culture characteristics, and student (Law No. 20 year 2003 about the national education system). Related to the implementation of this curriculum, the school has full authority and responsibility to develop strategies and set priorities in education. The keywords of this curriculum are the local wisdom, self-development activities, mastery learning and life skills (Retnawati et al, 2016).

In 2013 a new curriculum was introduced in primary and secondary schools in Indonesia, it was the 2013 curriculum. The 2013 Curriculum is a new curriculum started to be implemented officially since 2013/2014 academic year. The 2013 Curriculum emphasizes more on soft skills and hard skills balance. It is developed to improve and balance soft and hard skills consisting of affective, psychomotor, and cognitive aspects (Kurniawan, 2015).

The curriculum is very different from the previous curriculum. In this curriculum, education does not only emphasize knowledge and skills, but also changes teaching approach and assessment system. The objective of the new curriculum will be attained by paying attention to the educational content, switching the learning paradigm from the teacher centered approach into student-centered approach and using competence-based assessment, replacing the testbased assessment by authentic-based assessment that measures attitude, knowledge, and skills based on the learning process and learning results (Retnawati et al, 2016).

The development of it aims to encourage student to be able to perform observations, aks questions, reasons about things, and communicate (present) what they gain or know after receiving information during the lesson. (Puskurbuk, 2012) The currently developed learning model is directed towards the goal of encouraging students to find out by themselves from various sources of observation and by not being told.

The aim of a curriculum change is to improve the quality of human resources and improve the competitiveness of the nation, all along with the development of science, technology and art. Expected changes in human resources quality are increased productivity, creativity, innovation and affective skills, by strengthening the competencies of attitudes, knowledge and skills. These are done through implementation of education; by changing the learning paradigm to constructivism, from students who only accept the material to students who are able to form their own knowledge by using competence-based assessment and authentic class assessment.

The 2013 curriculum contains 4 core competencies, which are competence in social attitudes, spiritual attitudes, knowledge, and 
skills (Minister of Education and Culture, 2013). Each competency is then translated into several basic competencies. The four core competencies are each given the same emphasis, which is what distinguishes the 2013 curriculum from the prior curriculum, the KTSP. Emphasis on the prior curriculum is only focused on the cognitive competence, in contrast to the new curriculum which emphasizes more on the attitude and skill competency towards students. In line with this, the 2013 curriculum is a form of refinement of the prior curriculum.

The 2013 curriculum is made based on juridical, philosophical, theoretical, and empirical foundation. There are several elements of change in the curriculum, including the Changing Elements of Passing Competencies, Changing elements in Subject Position (Content), Learning Approach (content), Curriculum structure (Subjects and time allocation) content, Learning process, Learning achievements assessment, and Extracurricular.

According to Halim (2017) the 2013 curriculum emphasizes more on the integrated curriculum. He stated that this approach model has 3 characteristics, which are: First, learning process must be meaningful; Second, learning process must be discovery learning (learning to find inventions, finding out); Third, learning must be constructivism (learning constructively according to constructivism theory). 2013 curriculum is an improvement of the prior curriculum, which is the KTSP. This 2013 curriculum is made based on a juridical, philosophical, theoretical and empirical foundation. According to Jerome Bruner in The Process of Education (Ahid, 2006) as quoted by $\mathrm{S}$. Nasution, he suggested that curriculum design should be based on the structure of scientific disciplines. The curriculum of a subject must be based on a fundamental understanding that can be obtained from the underlying principles and give structure to a scientific discipline. There are three approaches in a development of the academic curriculum: First, Students learn how to obtain and test facts and not just remember them and is a knowledge structure approach. Second, an approach that responds to the development of society which demands more comprehensive integrated knowledge models. Lessons are composed out of units of learning, and within the units of learning the limitations of the subjects are gone. Organizing lesson themes is based on natural phenomena, scientific work processes and existing and integrative problems. Third, the approach taken at fundamentalist schools. They still teach based on subjects by emphasizing reading, writing and solving problems. Hyman (Hernawan, 2000) explains the contents in the curriculum are divided into three elements: knowledge (eg facts, explanations, principles and definitions; and then skills and processes, and then values (eg beliefs about good and bad, true-false and beautiful-bad) The basis of this paper is contents of the curriculum, especially knowledge in mathematics. Knowledge in mathematics includes coverage in each level related to the concepts of numbers, geometry, measurement, statistics and algebra.

\section{RESEARCH METHOD}

This research is a study of literature. The procedure of data processing is done by collecting field notes, analyzing and categorizing documents and interpreting them. Data analysis is the process of organizing and sorting data into patterns, categories and basic description units so that themes can be found and a working hypothesis can be formulated as suggested by data (Moleong, 2006).

The data analysis technique carried out in this research is collecting and organizing supporting documents, and then inputting the data, processing and interpreting it, and finally presenting it in a descriptive form. Data from the 2013 and KTSP curriculum are then presented in a table to look for similarities and differences from both curriculums. Furthermore, data analysis is done by determining the relationship of the materials in both curriculums, depth of material, and cognitive development of elementary school students. This research aims to provide input related to the competencies of mathematics subjects in elementary schools, especially in the KTSP curriculum and 2013 curriculum.

\section{RESULTS AND DISCUSSION}

Researcher used prior curriculum, in this case the standard of competence and basic competencies contained in the KTSP curriculum competency standards. Wijaya, A. (2015), The Indonesian national curriculum mandates that mathematics education must be relevant to the needs of life and should offer students opportunities to develop the ability to apply their knowledge in society. Furthermore, for the new curriculum, the 2013 curriculum, researcher used changes in core competencies and basic competencies from the Directorate General of Elementary and Secondary Education in 2016. According to Royani (2018), one of the functions 
of the curriculum is to be an instrument to achieve educational goals which basically have basic components and supporting components that are interrelated and interacted with each other. The curriculum component explored in this study are the concept of numbers, geometry, measurement and statistics. Below is a study table results of the mathematics curriculum in the 2013 KTSP and Curriculum. Table 1 contains study results of both KTSP and 2013 curriculum.

Table 1. Comparative Basic Competencies Reduction Results for Basic Numerical Concept in Grade 1

\begin{tabular}{|c|c|}
\hline KTSP Curriculum & 2013 Curriculum \\
\hline 1.1 Count many objects & $\begin{array}{l}3.1 \text { Explain the meaning } \\
\text { of a whole number of up } \\
\text { to } 99 \text { to count members } \\
\text { in a group of objects }\end{array}$ \\
\hline 1.2 Sort lots of objects & $\begin{array}{l}3.2 \text { Describe up to two } \\
\text { numbers and place } \\
\text { values, using a collection } \\
\text { of concrete objects and } \\
\text { how to read them }\end{array}$ \\
\hline $\begin{array}{l}1.3 \text { Add and subtract } \\
\text { numbers to } 20\end{array}$ & $\begin{array}{l}3.3 \text { Compare two } \\
\text { numbers by using a } \\
\text { group of concrete objects }\end{array}$ \\
\hline $\begin{array}{l}1.4 \text { Resolve problems } \\
\text { related to addition and } \\
\text { subtraction to } 20\end{array}$ & $\begin{array}{l}\text { 3.4 Explain and add and } \\
\text { subtract numbers } \\
\text { involving numbers up to } \\
99 \text { in daily life context } \\
\text { and associate addition } \\
\text { and subtraction }\end{array}$ \\
\hline $\begin{array}{l}\text { 4.3 Determine place } \\
\text { values of tens and units }\end{array}$ & $\begin{array}{l}3.5 \text { Know the pattern of } \\
\text { numbers related to a } \\
\text { collection of objects / } \\
\text { images / movements or } \\
\text { others }\end{array}$ \\
\hline $\begin{array}{l}\text { 4.4 Add and subtract two } \\
\text { numbers }\end{array}$ & \\
\hline $\begin{array}{l}4.5 \text { Use the exchange } \\
\text { and grouping binary } \\
\text { operations }\end{array}$ & \\
\hline $\begin{array}{l}4.6 \text { Resolves problems } \\
\text { that involve addition and } \\
\text { subtraction of two } \\
\text { numbers }\end{array}$ & \\
\hline 1.2 Sort lots of objects & \\
\hline
\end{tabular}

Table 2. Comparative Basic Competencies Reduction Results for Geometry Concept in Grade 1

\begin{tabular}{|l|l|}
\hline KTSP Curriculum & \multicolumn{1}{|c|}{$\mathbf{2 0 1 3}$ Curriculum } \\
\hline $\begin{array}{l}\text { 3.1 Group various } \\
\text { simple solid figures } \\
\text { (beams, prisms, balls and } \\
\text { cones) }\end{array}$ & $\begin{array}{l}\text { 3.6 Get to know } \\
\text { geometry and two- } \\
\text { dimensional shapes } \\
\text { using various concrete } \\
\text { objects }\end{array}$ \\
\hline
\end{tabular}

\begin{tabular}{|l|l|}
\hline $\begin{array}{l}\text { 3.2 Determine the } \\
\text { sequence of similar } \\
\text { objects according to their } \\
\text { magnitude }\end{array}$ & $\begin{array}{l}\text { 3.7 Identify two- } \\
\text { dimensional shapes } \\
\text { using various concrete } \\
\text { objects }\end{array}$ \\
\hline $\begin{array}{l}\text { 6.1 Know triangles, } \\
\text { squares, and circle }\end{array}$ & $\begin{array}{l}\text { 3.8 Get to know and } \\
\text { determine length and } \\
\text { weight with non- } \\
\text { standard units using } \\
\text { concrete objects / } \\
\text { situations }\end{array}$ \\
\hline $\begin{array}{l}\text { 6.2 Group two- } \\
\text { dimensional shapes } \\
\text { according to their shape }\end{array}$ & $\begin{array}{l}\text { 3.9 Compare weight, } \\
\text { length, length of time, } \\
\text { and temperature using } \\
\text { concrete objects / } \\
\text { situations }\end{array}$ \\
\hline
\end{tabular}

Table 3. Comparative Basic Competencies Reduction Results for Measurement Concept in Grade 1

\begin{tabular}{|l|l|}
\hline \multicolumn{1}{|c|}{ KTSP Curriculum } & \multicolumn{1}{|c|}{$\mathbf{2 0 1 3}$ Curriculum } \\
\hline $\begin{array}{l}\text { 2.1 Determine the } \\
\text { duration of an event }\end{array}$ & $\begin{array}{l}\text { 3.8 Get to know and } \\
\text { determine the length and } \\
\text { weight with non- } \\
\text { standard units using } \\
\text { concrete objects / } \\
\text { situations }\end{array}$ \\
\hline $\begin{array}{l}\text { 5.1 Comparing weight } \\
\text { (light, heavy) }\end{array}$ & $\begin{array}{l}\text { 3.9 Comparing weight, } \\
\text { length, length of time, } \\
\text { and temperature using } \\
\text { concrete objects / } \\
\text { situations }\end{array}$ \\
\hline $\begin{array}{l}\text { 5.2 Resolve problems } \\
\text { related to object weight }\end{array}$ & \\
\hline
\end{tabular}

Tables 1 and 2 show that in the numerical concept, materials in the 2013 curriculum explains more about numbers and arranges the symbol of numbers using concrete objects, whereas KTSP curriculum basically only explains numbers by numerating, sorting, adding and subtracting numbers up to 20 . In KTSP curriculum, the concept of the number used is the integer. Meanwhile, in the 2013 curriculum the concept of numbers discussed was the whole number. What is expected in the KTSP curriculum and the 2013 curriculum is actually similar. The integers referred to in KTSP are integers that have been limited to 1 to 20. It's just that the range of numerical concept in the prior curriculum is narrower than the 2013 curriculum. For grade 1 elementary school, the 2013 curriculum demands children to count objects up to 99 . In the 2013 curriculum material for grade I numerical concept, the basic competencies are to explain and present numbers of up to 99 which correspond to many members of group of object.

The Geometry concept introduces the concept of two-dimensional shapes, however, 
two-dimensional shapes introduced in the KTSP curriculum is specific to triangles, squares, and circles. In the 2013 curriculum, the material does not explain specifically what shape is given to students, but uses concrete objects.

The concept of measurement in table 3 shows that the grade 1 measurement material in KTSP curriculum has been given only to the concept of light-weighted and the duration of an event. Whereas in the 2013 curriculum, the concept of measurement is broader, such as length, weight, time and temperature using concrete objects. Not only that, the measurement in the first grade is deeper, for example students are expected to be able to compare the size of weight, length and time.

Table 4. Comparative Basic Competencies Reduction Results for Numerical Concept in Grade 2

\begin{tabular}{|c|c|}
\hline KTSP Curriculum & 2013 Curriculum \\
\hline $\begin{array}{l}\text { 1.1 Comparing numbers } \\
\text { up to } 500\end{array}$ & $\begin{array}{l}3.1 \text { Explain the meaning } \\
\text { of whole number and } \\
\text { determine the symbol } \\
\text { based on its place value } \\
\text { while using concrete } \\
\text { models and how to read } \\
\text { it }\end{array}$ \\
\hline $\begin{array}{l}\text { 1.2 Sorting numbers up } \\
\text { to } 500\end{array}$ & $\begin{array}{l}3.2 \text { Compare two whole } \\
\text { numbers }\end{array}$ \\
\hline $\begin{array}{l}\text { 1.3 Determine place } \\
\text { values for hundreds, } \\
\text { tens, and units }\end{array}$ & $\begin{array}{l}3.3 \text { Explain and perform } \\
\text { addition and subtraction } \\
\text { involving whole } \\
\text { numbers up to } 999 \text { in } \\
\text { daily life context and } \\
\text { associate addition and } \\
\text { subtraction }\end{array}$ \\
\hline $\begin{array}{l}\text { 1.4 Add and subtract } \\
\text { numbers up to } 500\end{array}$ & $\begin{array}{l}3.4 \text { Explain } \\
\text { multiplication and } \\
\text { division involving whole } \\
\text { numbers up to } 100 \text { in } \\
\text { daily life context and } \\
\text { associate multiplication } \\
\text { and division }\end{array}$ \\
\hline $\begin{array}{l}\text { 3.1 Do multiplication } \\
\text { resulting in numbers } \\
\text { with two digits ( } 2 \text { nd } \\
\text { semester) }\end{array}$ & $\begin{array}{l}3.5 \text { Explain the value } \\
\text { and equality of currency }\end{array}$ \\
\hline $\begin{array}{l}\text { 3.2 Do division with } \\
\text { numbers in two digits }\end{array}$ & $\begin{array}{l}\text { 3.7 Explain the fraction } \\
\text { numbers of } \frac{1}{3}, \frac{1}{3} \text {, and } \\
\text { using concrete objects in } \\
\text { daily life context }\end{array}$ \\
\hline $\begin{array}{l}\text { 3.3 Perform mix } \\
\text { operations }\end{array}$ & \\
\hline
\end{tabular}

Table 5. Comparative Basic Competencies Reduction Results for Geometry Concept in Grade 2

\begin{tabular}{|l|l|}
\hline \multicolumn{1}{|c|}{ KTSP Curriculum } & \multicolumn{1}{|c|}{$\mathbf{2 0 1 3}$ Curriculum } \\
\hline $\begin{array}{l}\text { 4.1 Group two- } \\
\text { dimensional shapes }\end{array}$ & $\begin{array}{l}\text { 3.9 Explain lines with } \\
\text { concrete models of two- } \\
\text { dimensional and solid } \\
\text { figures }\end{array}$ \\
\hline $\begin{array}{l}\text { 4.2 Get to know the } \\
\text { sides of two-dimensional } \\
\text { shapes }\end{array}$ & $\begin{array}{l}\text { 3.10 Explain two- } \\
\text { dimensional and solid } \\
\text { figures based on their } \\
\text { characteristics }\end{array}$ \\
\hline $\begin{array}{l}\text { 4.3 Get to know the } \\
\text { angles of solid figures }\end{array}$ & $\begin{array}{l}\text { 3.11 Explain line } \\
\text { patterns if a two- } \\
\text { dimensional and solid } \\
\text { figure using concrete } \\
\text { models }\end{array}$ \\
\hline
\end{tabular}

Table 6. Comparative Basic Competencies Reduction Results for Measurement Concept in Grade 2

\begin{tabular}{|l|l|}
\hline \multicolumn{1}{|c|}{ KTSP Curriculum } & \multicolumn{1}{|c|}{$\mathbf{2 0 1 3 \text { Curriculum }}$} \\
\hline $\begin{array}{l}\text { 2.1 Use a time } \\
\text { measuring instrument in } \\
\text { hours }\end{array}$ & $\begin{array}{l}\text { 3.6 Explain and } \\
\text { determine length } \\
\text { (including distance), } \\
\text { weight and time in a } \\
\text { standard measurement } \\
\text { unit in daily life context }\end{array}$ \\
\hline $\begin{array}{l}\text { 2.2 Use frequently used } \\
\text { standard and non- } \\
\text { standard measurement } \\
\text { tools }\end{array}$ & $\begin{array}{l}\text { 3.8 Explain and } \\
\text { determine length } \\
\text { (including distance), } \\
\text { weight and time in a } \\
\text { standard measurement } \\
\text { unit in daily life context }\end{array}$ \\
\hline $\begin{array}{l}\text { 2.3 Use a weight } \\
\text { measuring tool }\end{array}$ & $\begin{array}{l}\text { 2.4 Solve problems } \\
\text { associated with object } \\
\text { weight }\end{array}$ \\
\hline
\end{tabular}

Table 4 explain that numerical concept is still given in the second grade, where students continue to learn and compare numbers. The difference between numerical concept in grade 2 in the KTSP and 2013 curriculum is how much number is given. In the KTSP curriculum, numbers are introduced to students up to 500 while in the 2013 curriculum numbers are introduced up tp 999. In the KTSP curriculum, multiplication and division operation are started to introduced in the second grade. Meanwhile, on the 2013 curriculum, second grade students are expected to be able to operate addition and subtraction up to one thousand, and operate multiplication and division up to five hundred.

The material scope for the geometry concept can be seen in table 5 in grade 2 . The 
KTSP curriculum is still talking about twodimensional shapes, learning about lines and angles, but in the 2013 curriculum, second grade students are talking about solid figures. Not only that, the concept of two-dimensional shapes has reached the stage of mentioning the characteristics possessed by two-dimensional shapes and also the understanding of lines.

From Table 6, in the concept of measurement in grade 2, the KTSP curriculum is still learning about the concept of weight measurement and how to use a weight measuring tool but in the 2013 curriculum, students in grade 2 have arrived at the concept of determining length, weight and distance.

Table 7. Comparative Basic Competencies Reduction Results for Numerical Concept in Grade 3

\begin{tabular}{|c|c|}
\hline KTSP Curriculum & 2013 Curriculum \\
\hline $\begin{array}{l}\text { 1.1 Determine the place } \\
\text { of a number in the } \\
\text { number line }\end{array}$ & $\begin{array}{l}3.1 \text { Explain operations of } \\
\text { whole numbers }\end{array}$ \\
\hline $\begin{array}{l}\text { 1.2 Operate addition and } \\
\text { subtraction of a 3-digit } \\
\text { number }\end{array}$ & $\begin{array}{l}\text { 3.2 Explain whole } \\
\text { numbers and simple } \\
\text { fractions (such as } \frac{1}{2}, \frac{1}{3} \text {, } \\
\text { and } \frac{1}{4} \text { ) shown on a } \\
\text { number line }\end{array}$ \\
\hline $\begin{array}{l}\text { 1.3 Operate } \\
\text { multiplication and } \\
\text { division that resulted in } \\
\text { 3-digit numbers }\end{array}$ & $\begin{array}{l}\text { 3.3 Declare a number as } \\
\text { a result of addition, } \\
\text { subtraction, } \\
\text { multiplication, or } \\
\text { division from two whole } \\
\text { numbers }\end{array}$ \\
\hline $\begin{array}{l}\text { 1.4 Perform mix } \\
\text { operation }\end{array}$ & $\begin{array}{l}3.4 \text { Generalize the } \\
\text { concept of fraction as a } \\
\text { part of a whole using } \\
\text { concrete objects }\end{array}$ \\
\hline $\begin{array}{l}1.5 \text { Solve problems } \\
\text { associated with money }\end{array}$ & $\begin{array}{l}3.5 \text { Explain and operate } \\
\text { addition and subtraction } \\
\text { of fractions with the } \\
\text { same denominator }\end{array}$ \\
\hline $\begin{array}{l}\text { 3.1 Understand simple } \\
\text { fraction }\end{array}$ & \\
\hline $\begin{array}{l}\text { 3.2 Compare simple } \\
\text { fraction } \\
\text { 3.3 Solve problems } \\
\text { associated with simple } \\
\text { fraction }\end{array}$ & \\
\hline
\end{tabular}

Table 8. Comparative Basic Competencies Reduction Results for Measurement Concept in Grade 3

\begin{tabular}{|l|l|}
\hline KTSP Curriculum & \multicolumn{1}{|c|}{$\mathbf{2 0 1 3}$ Curriculum } \\
\hline $\begin{array}{l}\text { 2.1 Choose a } \\
\text { measurement tool that } \\
\text { according to its function } \\
\text { (meter, scales, or clock) }\end{array}$ & $\begin{array}{l}\text { 3.6 Explain and } \\
\text { determine the time } \\
\text { period of an event }\end{array}$ \\
\hline $\begin{array}{l}\text { 2.2 Use a measurement } \\
\text { tool in problem solving }\end{array}$ & $\begin{array}{l}\text { 3.7 Describe and } \\
\text { determine the connection } \\
\text { between time, length, } \\
\text { and weight units } \\
\text { frequently used on a } \\
\text { daily basis }\end{array}$ \\
\hline $\begin{array}{l}\text { 2.3 Get to know the } \\
\text { connection between } \\
\text { time, length, and weight } \\
\text { units }\end{array}$ & \\
\hline
\end{tabular}

Table 9. Comparative Basic Competencies Reduction Results for Geometry Concept in Grade 3

\begin{tabular}{|c|c|}
\hline KTSP Curriculum & 2013 Curriculum \\
\hline $\begin{array}{l}\text { 4.1 Identify various two- } \\
\text { dimensional shapes } \\
\text { according to their } \\
\text { characteristics and } \\
\text { elements }\end{array}$ & $\begin{array}{l}\text { 3.8 Explain and } \\
\text { determine area and } \\
\text { volume in non-standard } \\
\text { units with concrete } \\
\text { objects }\end{array}$ \\
\hline $\begin{array}{l}4.2 \text { Identify various two- } \\
\text { dimensional shapes } \\
\text { according to their } \\
\text { characteristics and } \\
\text { elements }\end{array}$ & $\begin{array}{l}\text { 3.9 Explain folded } \\
\text { symmetry and twist } \\
\text { symmetry of a shape } \\
\text { using concrete objects }\end{array}$ \\
\hline $\begin{array}{l}5.1 \text { Calculate the } \\
\text { perimeters of a rectangle } \\
\text { and square }\end{array}$ & $\begin{array}{l}\text { 3.10 Explain and } \\
\text { determine perimeters of } \\
\text { a two-dimensional shape }\end{array}$ \\
\hline $\begin{array}{l}5.2 \text { Calculate the area of } \\
\text { a square and rectangle }\end{array}$ & $\begin{array}{l}3.11 \text { Explain angles, type } \\
\text { of angles (right angle, } \\
\text { acute angle and obtuse } \\
\text { angle) and non-standard } \\
\text { measurement units }\end{array}$ \\
\hline $\begin{array}{l}5.3 \text { Solve problems } \\
\text { associated with } \\
\text { perimeters and area } \\
\text { measurements of square } \\
\text { and rectangle }\end{array}$ & $\begin{array}{l}3.12 \text { Analyze various } \\
\text { shapes by their } \\
\text { characteristics }\end{array}$ \\
\hline
\end{tabular}

Table 10. Comparative Basic Competencies Reduction Results for Statistics Concept in Grade 3

\begin{tabular}{|l|l|}
\hline KTSP Curriculum & $\mathbf{2 0 1 3}$ Curriculum \\
\hline & $\begin{array}{l}\text { 3.13 Explain data associated } \\
\text { with students served on a } \\
\text { pictograph }\end{array}$ \\
\hline
\end{tabular}


Table 7 explains that the grade 3 numerical concept in the KTSP curriculum still discusses addition, subtraction, multiplication and also division operations but is explained broader, up to 3-digit numbers. An addition to the numerical concept is the location of a number in the number line. Not only that, a simple fraction concept has also been introduced in grade 3 , even though still a simple introduction. Whereas in the 2013 curriculum, the scope of the material was supplemented by fraction counting operations, such as the addition and subtraction of fractions which means that the fraction concept is a step forward than the second grade.

The concept of measurement in KTSP curriculum, shown in table 8 explains that the concept of measurement reaches the use of measuring tools but in the 2013 curriculum, the material emphasizes more on the relation between length, weight and time.

The geometry concept in grade 3 shown in table 9 explains that the KTSP curriculum in the Geometry concept explains the characteristics of a two-dimensional shape such as perimeters and area. The 2013 curriculum also introduces two dimensional and solid figures, which are area measurements, perimeters, and volume.

Table 10. Comparative Basic Competencies Reduction Results for Numerical Concept in Grade 4

\begin{tabular}{|l|l|}
\hline \multicolumn{1}{|c|}{ KTSP Curriculum } & \multicolumn{1}{|c|}{$\mathbf{2 0 1 3}$ Curriculum } \\
\hline $\begin{array}{l}\text { 1.1 Use operations } \\
\text { including mix operations } \\
\text { such as Greatest } \\
\text { Common Factor (GCF) } \\
\text { and Least Common } \\
\text { Multiple (LCM) }\end{array}$ & $\begin{array}{l}\text { 3.1 Understand } \\
\text { operations that involved } \\
\text { various form of fractions } \\
\text { (simple fractions, mixed } \\
\text { fractions, decimals, and } \\
\text { percent) }\end{array}$ \\
\hline $\begin{array}{l}\text { 1.2 Determine the cubed } \\
\text { root of a number }\end{array}$ & $\begin{array}{l}\text { 3.3 Explain and define a } \\
\text { number as results from } \\
\text { addition, subtraction, } \\
\text { multiplication, and } \\
\text { division of two whole } \\
\text { numbers or fractions and } \\
\text { decimals. }\end{array}$ \\
\hline $\begin{array}{l}\text { 1.3 Solve problems } \\
\text { associated in operation } \\
\text { such as the use of roots } \\
\text { and exponents }\end{array}$ & \\
\hline 1.4 Use mix operations & \\
\hline $\begin{array}{l}\text { 1.5 Define and round } \\
\text { numbers }\end{array}$ & \\
\hline $\begin{array}{l}\text { 2.3 Determine Least } \\
\text { Common Multiple } \\
\text { (LCM) of a Greatest } \\
\text { Common Factor (GCF) }\end{array}$ & \\
\hline & \\
\hline
\end{tabular}

\begin{tabular}{l} 
5.1 Simplify and sort \\
fractions \\
\hline $\begin{array}{l}\text { 5.2 Transform fractions } \\
\text { into decimals }\end{array}$ \\
5.3 Determine fraction \\
value from a certain \\
quality \\
5.4 Use operation \\
associated with various \\
shapes
\end{tabular}

Table 11. Comparative Basic Competencies Reduction Results for Geometry Concept in Grade 4

\begin{tabular}{|c|c|}
\hline & \\
\hline KTSP Curriculum & 2013 Curriculum \\
\hline $\begin{array}{l}2.1 \text { Get to know } \\
\text { discharge units }\end{array}$ & $\begin{array}{l}3.7 \text { Get to know } \\
\text { elements of a circle }\end{array}$ \\
\hline $\begin{array}{l}3.1 \text { Calculate a shape } \\
\text { area that are consisted of } \\
\text { two shapes }\end{array}$ & $\begin{array}{l}3.8 \text { Analyze } \\
\text { characteristics of } \\
\text { irregular and regular } \\
\text { shapes }\end{array}$ \\
\hline $\begin{array}{l}3.2 \text { Calculate the area of } \\
\text { a circle }\end{array}$ & $\begin{array}{l}\text { 3.9 Sorting polygons by } \\
\text { symmetry lines and } \\
\text { rotations }\end{array}$ \\
\hline & $\begin{array}{l}3.10 \text { Explain the } \\
\text { relations between lines } \\
\text { (parallel, intersect, } \\
\text { coincide) using concrete } \\
\text { models }\end{array}$ \\
\hline & $\begin{array}{l}3.11 \text { Understand } \\
\text { questionnaire as an } \\
\text { accurate instrument to } \\
\text { obtain specific } \\
\text { information }\end{array}$ \\
\hline & $\begin{array}{l}\text { 3.12 Explain and } \\
\text { determine angular sizes } \\
\text { of a shape in standard } \\
\text { units using a protractor }\end{array}$ \\
\hline & $\begin{array}{l}3.14 \text { Understand a } \\
\text { sector, equalities of arc, } \\
\text { prism, cylinder, } \\
\text { pyramids, and cone to } \\
\text { solve a simple problem }\end{array}$ \\
\hline
\end{tabular}

Table 12. Comparative Basic Competencies Reduction Results for Measurements Concept in Grade 4

KTSP Curriculum 2013 Curriculum

3.2 Determine angular size that can be found on a daily basis at home, school, and surrounding environments with nonstandard measurement units and the angle measurement includes the angles between points of a compass and angles between two 
clock hands.

Table 13. Comparative Basic Competencies Reduction Results for Statistics Concept in Grade 4

\begin{tabular}{|c|c|}
\hline KTSP Curriculum & 2013 Curriculum \\
\hline $\begin{array}{l}\text { 4.1 Collecting and } \\
\text { understanding data }\end{array}$ & $\begin{array}{l}3.4 \text { Comparing } \\
\text { meaning/definition of } \\
\text { mean, median, and mode } \\
\text { from different but } \\
\text { similar groups of data }\end{array}$ \\
\hline $\begin{array}{l}4.2 \text { Processing and } \\
\text { serving the data in tables }\end{array}$ & $\begin{array}{l}\text { 3.5 Find empirical } \\
\text { opportunities from outer } \\
\text { data that might be } \\
\text { obtained based on some } \\
\text { types of related data } \\
\text { processed by using } \\
\text { tables and graphic } \\
\text { charts. }\end{array}$ \\
\hline $\begin{array}{l}4.3 \text { Understanding } \\
\text { presented data }\end{array}$ & $\begin{array}{l}3.13 \text { Comparing and } \\
\text { understanding } \\
\text { meaning/definition of } \\
\text { mean, median, and mode } \\
\text { from two different but } \\
\text { similar groups of data }\end{array}$ \\
\hline $\begin{array}{l}\text { 7.1 Serving data into } \\
\text { tables and pictograph, } \\
\text { bar charts, and pie charts }\end{array}$ & \\
\hline $\begin{array}{l}7.2 \text { Determine mean and } \\
\text { mode from a group of } \\
\text { data }\end{array}$ & \\
\hline $\begin{array}{l}\text { 7.3 Sorting obtained data } \\
\text { from the highest to the } \\
\text { lowest value }\end{array}$ & \\
\hline $\begin{array}{l}7.4 \text { Understanding } \\
\text { processed data }\end{array}$ & \\
\hline
\end{tabular}

Table 10 explains about basic competencies in the fourth grade of the KTSP curriculum. The table shows that students are still familiar with the numerical concept, which is mixed counting operations. Not only that but also the concepts of LCM, GCF, interpretation, rounding, roots and exponents. The concept of discharge has also been introduced to 4th grade students. But in the 2013 curriculum, the material still emphasized in mixed counting operations, such as fractions. The concept of fractions is more detailed and wide, for example fractions can transform into mix fraction, decimals, and percent.

Based on table 12, the geometry concept in the KTSP curriculum still addresses twodimensional shapes especially about calculating the area. The geometry material in the 2013 curriculum is increasingly more specific and complete. The concepts of geometry that are introduced are circles, irregular and regular shapes, symmetry lines, symmetry rotation and also angular measurements. Angle measurement in grade 4 has reached the stage where students have to be able to use standard measuring instruments and also non-standard measuring instruments. Standard measuring instruments for angles are protractors. In the concept of solid figures, students already understand about sectors, the similarity of protractors, prisms, cylinders, pyramids, and cones to solve simple problems.

Based on table 13, the statistical concept in the KTSP curriculum has begun with the collection, processing and presentation of statistical data. But in the 2013 curriculum, the material is far more broad. The students are encouraged to understand mean, median, mode from a group of data and processing them in tables and graphic charts.

Table 14. Comparative Basic Competencies Reduction Results for Numerical Concept in Grade 5

\section{KTSP Curriculum}

1.1 Use counting operations with integers while using their traits, rounding and defining

1.2 Use prime factors to determine LCM and GCF

\section{Curriculum}

3.1 Explain and operate addition and subtraction of two fractions with different denominators

3.2 Understand various forms of fractions (simple fractions, mixed fractions, decimals, and percent) and can transform fractions into decimals and operate multiplication and division

1.3 Use counting operations to calculate integers

3.3 Choose a problemsolving procedure by analyzing relation between symbol, relevant information, and pattern observation

1.4 Calculate simple exponents and roots

3.4 Get to know the concept of comparison and scale

1.5 Solve problems associated with LCM and GCF

3.5 Get to know and draw maps of an object and the coordinate system

5.1 Transform fractions into percent and decimals, and vice versa

3.9 Understand various forms of fractions (simple fractions, mixed fractions, decimals, and percent) and can transform fractions into decimals

5.2 Add and subtract 


\begin{tabular}{l} 
various forms of \\
fractions \\
\hline 5.3 Multiply and divide \\
various forms of \\
fractions \\
\hline $\begin{array}{l}\text { 5.4 Use fractions in } \\
\text { comparison and scale }\end{array}$ \\
\hline
\end{tabular}

Table 15. Comparative Basic Competencies Reduction Results for Geometry Concept in Grade 5

\begin{tabular}{|l|l|}
\hline \multicolumn{1}{|c|}{ KTSP Curriculum } & \multicolumn{1}{|c|}{$\mathbf{2 0 1 3}$ Curriculum } \\
\hline $\begin{array}{l}\text { 3.1 Calculate the area of } \\
\text { a trapezoid and kite }\end{array}$ & $\begin{array}{l}\text { 3.6 Explain and find } \\
\text { structures of a solid } \\
\text { figure (such as cubes) }\end{array}$ \\
\hline $\begin{array}{l}\text { 3.2 Solve a problem } \\
\text { associated with cube and } \\
\text { block volume }\end{array}$ & \\
\hline $\begin{array}{l}\text { 4.1 Calculate volumes of } \\
\text { a cube and block }\end{array}$ & \\
\hline $\begin{array}{l}\text { 4.2 Solve a problem } \\
\text { associated with cube and } \\
\text { block volume }\end{array}$ & \\
\hline $\begin{array}{l}\text { 6.1 Identify } \\
\text { characteristics of a two- } \\
\text { dimensional shape }\end{array}$ & \\
\hline $\begin{array}{l}\text { 6.2 Identify } \\
\text { characteristics of solid } \\
\text { figures }\end{array}$ & \\
\hline $\begin{array}{l}\text { 6.3 Determine structures } \\
\text { of a simple solid figure }\end{array}$ & \\
\hline $\begin{array}{l}\text { 6.4 Investigate } \\
\text { characteristics of } \\
\text { geometry and symmetry }\end{array}$ & \\
\hline $\begin{array}{l}\text { 6.5 Solve a problem } \\
\text { associated with simple } \\
\text { solid figure }\end{array}$ & \\
\hline
\end{tabular}

Table 16. Comparative Basic Competencies Reduction Results for Measurement Concept in Grade 5

\begin{tabular}{|l|l|}
\hline \multicolumn{1}{|c|}{ KTSP Curriculum } & $\mathbf{2 0 1 3}$ Curriculum \\
\hline $\begin{array}{l}\text { 2.1 Write time using the } \\
\text { 24 hour time notation }\end{array}$ & \\
\hline $\begin{array}{l}\text { 2.2 Use counting } \\
\text { operation with time units }\end{array}$ & \\
\hline $\begin{array}{l}\text { 2.3 Calculate angle } \\
\text { measurement }\end{array}$ & \\
\hline $\begin{array}{l}\text { 2.4 Get to know distance } \\
\text { and speed units }\end{array}$ & \\
\hline $\begin{array}{l}\text { 2.5 Solve problems } \\
\text { associated with time, } \\
\text { distance, and speed }\end{array}$ & \\
\hline
\end{tabular}

Table 17. Comparative Basic Competencies Reduction Results for Statistics Concept in Grade 5

\begin{tabular}{|l|l|}
\hline \multicolumn{1}{|c|}{ KTSP Curriculum } & \multicolumn{1}{|c|}{$\mathbf{2 0 1 3}$ Curriculum } \\
\hline $\begin{array}{l}\text { 5.1 Simplify and sort } \\
\text { fractions }\end{array}$ & $\begin{array}{l}\text { 3.7 Explain student- } \\
\text { related data or how to } \\
\text { obtain }\end{array}$ \\
\hline $\begin{array}{l}\text { 3.8 Explain data } \\
\text { presentation related to } \\
\text { the student and compare } \\
\text { it with surrounding data } \\
\text { in the form of table, } \\
\text { pictograph, bar charts } \\
\text { and pie charts }\end{array}$ \\
$\begin{array}{l}\text { 3.10 Understanding the } \\
\text { concept of relative } \\
\text { frequency through } \\
\text { experiments and tables }\end{array}$ \\
\hline
\end{tabular}

Based on table 14 the concept of numbers in the KTSP curriculum, the material contains integer counting operations, Greatest Common Factor (GCF) and Least Common Multiple (LCM). Addition to the KTSP curriculum is the existence of exponents and roots, 24-hour time notation, angles and also distance and speed units. In the 2013 curriculum the material still discusses operations on fractions, such as multiplication and division operations. The concept of comparison and scale is also part of the 2013 curriculum.

In table 15, it shows that the geometry concept in grade 5 in KTSP curriculum covers the characteristics of two-dimensional shapes and solid figures. For the 2013 curriculum, the material is already at the stage of understanding the concept of diagonals in solid figures.

Based on table 16, the concept of measurement in grade 5 is in the KTSP curriculum which includes understanding the signs of time, angular size, and speed.

The statistics material shown in table 17 in the KTSP curriculum have not discussed the statistical data in detail, but in the 2013 curriculum, they have discussed statistics in whole, such as the presentation of data. There are materials about Greatest Common Factor (GCF) and Least Common Multiple (LCM) in the KTSP curriculum, but not in the 2013 curriculum. In 2013 Curriculum there is a material about data analyzing while in KTSP there is no such material. The materials in grade 5 KTSP curriculum includes traits of number rounding, mixed integer operations, simple exponents and roots, time units, angle measurements, units of distance and speed, trapezoidal and kite area, 
shapes, and symmetry while in the 2013 curriculum there is no such material.

Table 18. Comparative Basic Competencies Reduction Results for Numerical Concept in Grade 6

\begin{tabular}{|l|l|}
\hline \multicolumn{1}{|c|}{ KTSP Curriculum } & \multicolumn{1}{|c|}{$\mathbf{2 0 1 3}$ Curriculum } \\
\hline $\begin{array}{l}\text { 1.1 Use operations } \\
\text { including mix operations } \\
\text { such as Greatest } \\
\text { Common Factor (GCF) } \\
\text { and Least Common } \\
\text { Multiple (LCM) }\end{array}$ & $\begin{array}{l}\text { 3.1 Explain and operate } \\
\text { addition and subtraction } \\
\text { of two fractions with } \\
\text { different denominators }\end{array}$ \\
\hline $\begin{array}{l}\text { 1.2 Determine cubed } \\
\text { root of a number }\end{array}$ & $\begin{array}{l}\text { 3.2 Explain and operate } \\
\text { multiplications of a } \\
\text { fraction and decimal }\end{array}$ \\
\hline $\begin{array}{l}\text { 1.3 Solve problems that } \\
\text { associated with } \\
\text { operations including the } \\
\text { use of roots and } \\
\text { exponents }\end{array}$ & $\begin{array}{l}\text { 3.9 Understand the } \\
\text { forms of fractions } \\
\text { (simple fraction, mix } \\
\text { fraction, decimal, and } \\
\text { percent) and that they } \\
\text { are transformable }\end{array}$ \\
\hline $\begin{array}{l}\text { 1.4 Calculate simple } \\
\text { exponents and roots }\end{array}$ & \\
\hline $\begin{array}{l}\text { 1.5 Solve problems that } \\
\text { associated with Greatest } \\
\text { Common Factor (GCF) } \\
\text { and Least Common } \\
\text { Multiple (LCM) }\end{array}$ & \\
\hline $\begin{array}{l}\text { 5.2 Transform fractions } \\
\text { into decimals }\end{array}$ & \\
\hline $\begin{array}{l}\text { 5.3 Determine the value } \\
\text { of a fraction from a } \\
\text { number }\end{array}$ & \\
\hline $\begin{array}{l}\text { 5.4 Use operations that } \\
\text { involves various forms } \\
\text { of fractions }\end{array}$ & \\
\hline $\begin{array}{l}5.5 \text { Solve problems } \\
\text { about comparison and } \\
\text { scale }\end{array}$ & \\
\hline
\end{tabular}

Table 19. Comparative Basic Competencies Reduction Results for Geometry Concept in Grade 6

\begin{tabular}{|l|l|}
\hline \multicolumn{1}{|c|}{ KTSP Curriculum } & \multicolumn{1}{|c|}{$\mathbf{2 0 1 3}$ Curriculum } \\
\hline $\begin{array}{l}\text { 3.1 Calculate the area of } \\
\text { a combined shape from } \\
\text { two shapes }\end{array}$ & $\begin{array}{l}\text { 3.5 Explain an determine } \\
\text { solid figure volume with } \\
\text { volume units and the } \\
\text { relation between cubed } \\
\text { roots and cubed } \\
\text { exponents. }\end{array}$ \\
\hline $\begin{array}{l}\text { 3.2 Calculate areas of a } \\
\text { circle }\end{array}$ & $\begin{array}{l}\text { 3.6 Get to know space } \\
\text { diagonal and shape } \\
\text { diagonal with rotation } \\
\text { symmetry }\end{array}$ \\
\hline $\begin{array}{l}\text { 3.3 Calculate the volume } \\
\text { of prism and tube }\end{array}$ & $\begin{array}{l}\text { 3.7 Sorting polygons } \\
\text { with symmetry lines and } \\
\text { rotation symmetry }\end{array}$ \\
\hline 6.4 Investigate & 3.8 Solving problems \\
\hline
\end{tabular}

\begin{tabular}{l|l|}
$\begin{array}{l}\text { characteristics of } \\
\text { geometry and symmetry }\end{array}$ & $\begin{array}{l}\text { associated with sectors, } \\
\text { prism, cylinder, } \\
\text { pyramids, and cones }\end{array}$ \\
\hline $\begin{array}{l}\text { 6.5 Solve problems } \\
\text { associated with shapes } \\
\text { and solid figures }\end{array}$ & \\
\hline
\end{tabular}

Table 20. Comparative Basic Competencies Reduction Results for Measurements Concept in Grade 6

\section{KTSP Curriculum}

2.1 Get to know
discharge units associated with discharge units

\section{Curriculum}

3.3 Explaining the comparison of two variables (speed as a comparison of distance and time, discharge as a comparison of volume and time)

3.4 Determine a problem solving procedure by analyzing relations between symbols, relevant information, and pattern observation

2.3 Measuring angles

2.4 Get to know distance and speed units 2.5 Solve problems associated with time, distance, and speed

Table 21. Comparative Basic Competencies Reduction Results for Statistics Concept in Grade 6

\begin{tabular}{|c|c|}
\hline KTSP Curriculum & 2013 Curriculum \\
\hline $\begin{array}{l}4.1 \text { Obtaining and } \\
\text { reading data }\end{array}$ & $\begin{array}{l}3.10 \text { Understanding } \\
\text { relative frequency } \\
\text { concept through } \\
\text { experiments and tables }\end{array}$ \\
\hline $\begin{array}{l}\text { 4.2 Processing and } \\
\text { serving data in tables }\end{array}$ & \\
\hline $\begin{array}{l}\text { 4.3 Defining presented } \\
\text { data }\end{array}$ & \\
\hline $\begin{array}{l}6.2 \text { Get to know location } \\
\text { coordinates of an object }\end{array}$ & \\
\hline $\begin{array}{l}\text { 7.1 Serving data into } \\
\text { tables and pictographs, } \\
\text { bar charts and pie charts }\end{array}$ & \\
\hline $\begin{array}{l}7.2 \text { Determine the mean } \\
\text { and mode from a group } \\
\text { of data }\end{array}$ & \\
\hline $\begin{array}{l}7.3 \text { Sorting data, } \\
\text { including the highest and } \\
\text { lowest data value }\end{array}$ & \\
\hline $\begin{array}{l}\text { 7.4 Defining processed } \\
\text { data }\end{array}$ & \\
\hline
\end{tabular}

Grade 6 numerical concept in the KTSP curriculum involved simple exponents and roots. 
Exponents and root are already introduced in grade 4 , but the difference is that using them with counting operations are more emphasized in grade 6.

Based on table 20, the measurement concept consists of understanding the units of discharge, measurement and speed. Grade 6 statistics in the KTSP curriculum are more detailed and more in-depth. However, there are no mentions about statistical data in the 2013 curriculum. For geometry concepts, 2013 curriculum alludes to volume, and students are encouraged to look for the relationship between the cubed exponent and the cube root.

Based on the results of the study note that this research has similarities and differences with research Anggraeni (2015), Fuadi et al (2016), Alhamuddin (2017), Hakim (2017), Miliyawati (2017), and Suandito (2017). The equation is in the mathematics subject curriculum which is used as the object of research. While the difference is in the focus of the problem being studied so that the results of the research are different.

\section{CONCLUSION}

The curriculum that applies in Indonesia, the KTSP curriculum and the 2013 curriculum has a range of material in mathematics, which are the concept of numbers, geometry, measurement, and statistics. Materials in the KTSP and 2013 curriculum gave different colors. Generally speaking, the differences in the scope of mathematics material within the KTSP and 2013 curriculums are as follows: in KTSP, Standard competencies are still comprehensive and basic competencies still use operational verbs and have not use the terms of high level thinking. The learning material given to the students are still general. Whereas in the 2013 curriculum, the material is more detailed and the use of the operational verbs is higher by using words such as explaining, comparing, identifying and adjusting problems on a daily basis.

\section{BIBLIOGRAPHY}

Alhamuddin. 2017. Studi Perbandingan Kurikulum Pendidikan Dasar Negara Federasi Rusia dan Indonesia. $A L$ MURABBI, 3 (2): 123-141.

Anggraeni, Dwi. 2015. Dampak Kebijakan Ujian Nasional terhadap Pengembangan Kurikulum Matematika Program Keahlian Tata Busana di SMK Negeri 3
Probolinggo. Jurnal Kebijakan dan Pengembangan Pendidikan, 3 (1): 1-7.

Dewi, R. 2007. Pengukuran Pengetahuan, Sikap dan Kepedulian Siswa SMA pada Lingkungan Hidup. (Tesis). Jakarta: Program Pascasarjana Universitas Indonesia.

Fuadi, Rahmi., et al. 2016. Peningkatkan Kemampuan Pemahaman dan Penalaran Matematis melalui Pendekatan Kontekstual. Jurnal Didaktika Matematika, 3 (1): 47-54.

Jufri, W. 2013. Belajar dan Pembelajaran Sains. Bandung: Pustaka Reka Cipta.

Kurniawan. 2015. The Implementation of The 2013 Curriculum In Learning Activities Conducted by The English Teacher of First Grade at Junior High School Makassar. Journal English Education, 1 (1): 131-144.

Laugsch, R.C. 2000. Scientific Literacy: A Conceptual Overview. Science Education, 84 (10): 71-94.

Miliyawati, Bety. 2017. Kurikulum dan Pembelajaran Matematika di Jepang Serta Perbandingannya dengan di Indonesia. BIORMATIKA Jurnal Ilmiah FKIP Universitas Subang, 4 (2): 1-15.

Retnawati, et al. 2016. Vocational High School Teachers' Difficulties in Implementing the Assessment in Curriculum 2013 in Yogyakarta Province of Indonesia. International Journal of Instruction, 9(1), 33-46.

Suandito, Billy. 2017 Bukti Informal dalam Pembelajaran Matematika. Al-Jabar: Jurnal Pendidikan Matematika, 8 (1): 1324.

Wasis. 2013. Merenungkan Kembali Hasil Pembelajaran Sains. Prosiding Seminar Nasional FMIPA Undiksha III Tahun 2013, 10-13.

Wijaya, A. 2015. Context-based mathematics tasks in Indonesia: Toward better practice and achievement. Utrecht University. 